\title{
Violence Against Seniors as a Social Concern
}

\section{KEY WORDS}

violence, domestic violence, seniors, prevention

\begin{abstract}
Smetanová Dorota, Violence Against Seniors as a Social Concern. Kultura - Społeczeństwo - Edukacja nr 2(10) 2016, Poznań 2016, pp. 85-93, Adam Mickiewicz University Press. ISSN 2300-0422. DOI 10.14746/kse.2016.10.7.

Despite the fact that the situation in our society is sufficiently legally treated, the issue of domestic violence at the senior is still only in its infancy. Intervention and prevention would not only avoided tampering with this group of people, but to offer procedures that would help at least reduce the risk. The paper is focused on the issue of violence on seniors as society-wide problem. It defines domestic violence, causes, forms and types of violence. In the end, it offers opportunities for protection and prevention.
\end{abstract}

\section{Introduction}

Violence itself is a heavy encroachment on fundamental human rights. It includes various activities that violate personal freedom, right to property, human integrity of an individual. Victims are often mainly people who are unable to defend themselves due to lack of mental, physical strength as in the case of children or senior citizens. Abuse of the elderly was first pointed out in the UK in 1975. This phenomenon was, for the first time, characterized as a social and political issue.

According to D. Sedláková (2013), within the last two decades, more and more attention has been paid to the issue of abuse of the elderly in research, politics and practice. The report from June 2011, issued by the Regional Office of the World Health Organization for Europe (WHO / Europe), reveals that every year 2.7\% (four million) of all people aged 60 and over experience physical abuse, 19.4\% (29 million) experience mental torture and abuse, 3.8\% (six million) financial abuse and $0.7 \%$ (one million) sexual abuse. 
According to the WHO definition, abuse of the elderly is a single or repeated act appearing in any relationship that causes harm or distress to an older person. The abuse is mainly understood as a mistreatment of a person taken care of characterized with higher degree of brutality and cruelty, disrespect and humiliation perceived by the victim as a huge injustice.

\section{Domestic violence}

Except for the terms violence or abuse of the elderly, there is also a term neglect used in literature. The difference between these terms is expressed by distinction of "hardness” of the act against the abused person. Neglect is described as a failure of a loved one in providing the necessary care with the purpose of avoiding any physical difficulty or mental distress against the vulnerable person. For example, failure to provide adequate food, clothing, medical care, medication and hygiene. Dehydration, malnutrition, unmade bed, lack of medicines or medical care, poor hygiene, uncut nails, hair, dirty clothes and bedding and so on can be considered as typical signs of care neglect. It is a difference between neglect intentional and neglect unintentional. Some use the terms active and passive neglect. Neglect will occur also at detailed questions about the daily regime, given medication or a patient's disease, where lack of information about senior is shown, due to lack of interest. (Haškovcová, 2004).

The term domestic violence is used also to indicate violent acts and neglect that take place in the context of "domestic" relationship especially in the family, whereas it also includes violence in partner relationships. In more details it refers to physical attacks in the form of thrusting, pinching, spitting, kicking, choking, burning, fist hitting, hitting with various objects, stabbing, throwing boiling liquids, maiming, pointing a gun, etc. and sexual violence. In general, the domestic violence means mental, social and economic violence, as well as repeated verbal attacks, swearing, harassment, humiliation, deprivation of liberty and contacts with relatives and friends, or access to financial and personal sources.

The most general characteristic of domestic violence is any violence, in which the victim and abuser are or were in any personal relationship. In this understanding, it does not include just violence against women but also against children, violence among siblings and the abuse and neglect of older people by their children. It is a violence done at home or within the family, which assumes close relationship between the victim and the abuser. It includes sexual, physical violence and mental or social abuse and neglect. There is no clear definition. Main feature of the violence is the intention. Violence is not a "coincidence” 
or "destiny." It's the consequence of certain human action, which can be described as intentional. Fear from physical violence and fear from being left to someone (something) is always also the fear from an impending mental disintegration. "Pain” and "threat" go hand in hand with violence. Pain is a common sign for abusers and their victims. Abusers cause the pain and their victims feel the pain. Pain can be imagined by both abuser and the victim in their imagination. This image, often more intense than in reality, can become a source of vision, which psychologically terrifies the victim even before the torture of violence begins. Pain tolerance borne by the victim is extremely individual and is subject to culture and anthropology.

Research show that although aging of the victim brings new form of domestic violence, a number of violent cases is directed at older people within the partnership. Sometimes the use of violence occurs in older age, when a man goes through mental changes and extreme jealousy appears.

Three quarters of violence against the retired women took place in the family circle, usually in partnerships.

Expert Group of the European Council on violence against the elderly published in 1993 a report Violence against elderly people (Violence against elderly people). Among other things in it, it states that „...efforts to present and describe the phenomenon of violence against elderly people encounters the question of the definition..." (Violence, 1993).

The problem is that a variety of terms to describe the violent behaviour against elderly people is used:

- physical abuse (eg. hitting, physical cruelty, sexual abuse, restriction of movement, intentional physical abuse leading to death, murder);

- mental abuse (eg. verbal attacks, threaten with violence, isolation, threaten with placing one into institutional care, dehumanisation of the life conditions for elderly people, underestimating older person, behaviour or attitudes leading to uncertainty);

- exploitation - material abuse (financial exploitation, withholding of income, retirement, exploiting a position of guardianship to the detriment of the elderly);

- denial of rights (denial of the rights guaranteed to all persons over national legislation);

- (active) neglect (leaving vulnerable, disabled or mentally disoriented person, who is incapable of taking care of himself/herself, placing person with reduced physical and mental abilities to the hospital or institution, failure to meet duties leading to injury or inability to use the law);

- (passive) neglect (neglect without a clear intention, however, leading to physical or mental harm). 
The most hidden form of all forms of domestic violence directed against

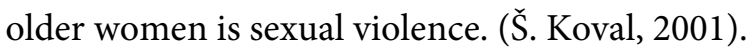

Social role of the old person results from the relationship between his social position of the retired person and consensual ideas of members of society. Elderly people often simply do not recognize the fact that they grow old, close their eyes in front of reality. They build negative attitude towards the younger generation and basically towards everything new. Thus, there is a risk of increasing generation gap. In the second half of the twentieth century, the old person started to get more attention not only as a patient, but also as a medium of internal social status of the retired person. Old man in Slovakia and the Czech countries is mostly sick, poor, with no savings, with no insurance, has no necessary psycho-dynamics of life, he sometimes perceives bad relations from the outside world and is disappointed from social development. An important question is, who the neglected, abused and tortured people are. These people are very often at risk of mistreatment by their future official nurse. Most of elderly people who live in the same household with younger people are mentally and emotionally abused. The vast majority of the population in Slovakia live in communities, either in their own homes, or home with their family at multi-generation family. They rarely stay with relatives. Elderly people in the vast majority are taken care of by family members, and therefore there may be a greater risk of abuse.

Only the last 40 years the issue of domestic violence against elderly people has been paid attention to. Also Z. Kalvach and Koval (2004) confirm that most attention is paid to the issue of violence against children, then violence against women and only with a great distance - and that only marginally - the violence against the elderly is mentioned. Both authors agree that domestic violence against the elderly has been reflected in the world only since 1975, but with 10 times less attention paid to than to other forms of domestic violence. Moreover, in the Czech Republic a topic of domestic violence for the elderly has been discussed only since the mid-90s of the 20th century, when also the first empirical research took place and scientific publications were issued on this topic. iolence is, according to Biggs, Phillipson and Kingston (1995) very complicated phenomenon and no unique and complex definition of this term exists, however, the exact definition is, according to their opinion, important from several reasons:

1. Definition of the issue refers to the existence of a serious social problem and leads to a better understanding of what the term comprises.

2. Clear definition helps experts to focus on domestic violence as a specific social problem and specify it against other topics.

3. Thirdly, the exact definition is needed to lead professionals the required direction in order to help and to enable needed intervention. 
Critical analysis of definitions is important also because professional discussion was so far limited to only selected topics of elder abuse, for example in health institutions and social care institutions, while the topic of domestic violence against the elderly (or violence against the elderly in the family) has been neglected. This incompliance can be seen also in the terminology used in relation with the violence against the elderly. Biggs, Phillipson and Kingston (1995) reflect the development of the terminology as follows:

- granny battering (Baker, 1975),

- elder abuse (O’Malley et al., 1979),

- elder mistreatment (Beachler, 1979),

- the battered elder syndrome (Block and Sinnott, 1979),

- elder maltreatment (Douglass et al., 1980),

- granny Bashing (Eastman and Sutton, 1982),

- old age abuse (Eastman, 1984),

- inadequate care of the elderly (Fulmer and O'Malley, 1987),

- granny abuse (Eastman, 1988),

- mis-care (Hocking, 1988).

\section{Reasons, theories and model of mistreatment with the elderly}

N. Špatenková 2011 identifies the reasons of violence against the elderly as follows:

- location model - source of exhausted nurse,

- theory of shift - imbalance between received and provided help between the older person and the abuser,

- political and economic theory - marginalism of elderly people in the society resting in, for example, social vulnerability, social exclusion,

- feministic theory - danger of despotisms and depression, stereotype of the woman taking care,

- psychopathology - says about mentally or emotionally disrupted aggressor,

- theory of social learning - emphasizes personal experience of the aggressor with child abuse.

G. Lubelcová, R. Džambazovič (2008) explain that these models are included into conceptual approaches to interpret torture, mistreatment and neglect of the elderly coming from the theory application explaining social behavior. In addition to these theories, they are talking about pragmatic approaches, based on the model of active intervention and lead to reflection of the organizations, which have to respond to the problem. 


\section{Types and forms of domestic violence against the elderly}

Although a number of forms and types may occur in all cases of domestic violence, a little specific options and scenarios are recorded in the domestic violence against the elderly. J. Voňková and M. Huňková (2004) define general kinds of domestic violence as physical, mental, sexual and economic abuse:

- physical - eg. pushing, hitting, hair pulling, kicking, sliding, threatening with guns, throwing objects, restraining the victim, pushing him/her to the corner.

Z. Kalvach (2004), emphasizing the elderly, characterizes the physical abuse of the elderly as pain causing, wounding and the denial of physical needs. He further adds possibilities of more sophisticated physical torture - a cool or cold water washing, food and medicaments denial, failure to provide help, if the older person suffers from pain. Špatenková and Ševčík (2011) point out that it is probably the most obvious and the roughest form of domestic violence with respect to consequences. They expand the range of attacks of the abuser for example hair plucking, hair plucking from the genital area, burning, or recklessness behind the wheel, or leaving the person at dangerous place;

- mental - includes mainly verbal form - e.g. swearing, different forms of humiliation and embarrassment, permanent checking of the course of the day, interrogations, threaten with crippling. Z. Kalvach (2004) extends the definition by reduction of self-esteem and self-confidence, emphasizing pathologic changes in the old age, threaten with relocation or placement in institutional care. Very serious is the disposal of items of particular emotional significance for the vulnerable older person. This phenomenon is described by D. Ševčík and N. Špatenková (2011) as a non-verbal mental violence;

- sexual - includes all sexual acts, which victims are forced to and undergo them involuntarily or unwillingly. According to D. Ševčík and N. Špatenková (2011) results from US statistics data point to the fact that one third to one half of abused women was at least once raped by her partner, and they expressed concern that the situation in Slovakia is not too different;

- economic - means stopping from possibility of victims to dispose of family or own funds. Z. Kalvach (2004) refers to financial and material abuse consisting of the enforcement of money or changing a will and an unfavorable transfer of property (apartment, house).

Z. Kalvach (2004) adds other types of abuse of the elderly at home:

- neglect of care - may be a failure to care for a dependent elderly person as a household member; 
- systematic abuse - so called abuse in the own interest by moving from family into institutional care, excessive social pressure to stay in institutional care.

\section{Profile of the violence victim in the old age}

According to Š. Koval (2001) the most common victims of abuse and neglect are:

- women, widows, aged 70-80 years, with less than secondary education,

- pensioners at the boundary of poverty, but also sufficiently wealthy old people,

- elderly people living in a household with relatives,

- defenseless and vulnerable persons with physical and mental decline.

\section{Elder abuse prevention}

K. Repková and B. Balogová (2013) declare that although there is an evidence that Slovakia copy this European-wide trend, there are only a few aimed and representative studies. Part of the preparation of the National Program for Active Ageing in Slovakia for 2014-2020, on which the Committee on Seniors of the Council of the Slovak Republic for Human Rights, National Minorities and Gender Equality cooperates with WHO / Europe, is also a task to analyze the extent of the elder abuse, based on which it will be possible to formulate policies on how to prevent this undesirable phenomenon in the future. The aim was to find elder abuse experience among the employees of social service institutions, to help overcome stereotypes, which still exist in the elder abuse. Currently, preventing elder abuse in different environments (in the family, community, services) becomes special and political priority. Professionals working in the area of residential care services are considered as important actors, who can help determine (diagnose) the various forms of violent behavior towards this group of people and help mitigate their consequences. Diagnosis of elder abuse and neglect is insufficient and underestimated. Based on experience, the doctors are less active and identify fewer cases as social workers and other professionals. One of the reasons is that it is not conventional for the doctors to perceive this phenomenon as a medical problem. The survey revealed that senior population risk include age discrimination, social exclusion, low income in the old age, which is insufficient for covering the most basic necessities of life, lack of services and care - unequal access to services, generational intolerance (job opportunities, leadership positions, housing), unfamiliarity with their problems and needs, 
underestimation of the need to treat the elderly - discrimination in approach to health services, lack of legal awareness and lack of information.

We agree with the definitions of Bérešová, which are divided into 3 levels: (Bérešova, 2002):

\section{- Individual level prevention}

Activity and engagement in the community, voluntary or charitable activities can also maintain contact with the outside world and thus avoid isolation and possibility to create opportunities for some form of violence to himself.

\section{- Family level prevention}

It should be focused on growing and strengthening generational bonds with an older relative. The vast majority of the elderly live in multigenerational family. They rarely live with other relatives. Those are the people who represent the risk group in terms of abuse by their own family members - informal nurses. The abuser is usually the spouse, partner, children and their partners. Less often they are distant relatives. In terms of prevention it is important to early detect risk families or informal nurses.

\section{- Community level prevention}

It focuses its activities on the development of new methods and forms of nursing care in the family. In this level, the interest of others in the community to participate in the programs to help the elderly should be also encouraged. They should be also encouraged to support public and private activities, which help families taking care for older family member. Community prevention is considered as publishing of cases of mistreatment and abuse of the elderly, encouraging citizens to notify early on signs of mistreatment and abuse of an older person.

\section{Conclusion}

Work and life with a dependent senior is really not easy. We cannot expect from the general public to keep sufficient emotional distance and not to let them absorb the feelings that many times lead to behavior similar to domestic violence. Despite the fact that seniors are the generation that takes more than gives - not only financially, they are living beings with a past and a future that also depends on us. Among them there are doctors, who were highly regarded by their patients, teachers, who earned the respect of their students, conductor admiring by their listeners, or doorman, who enlightened the mood of passers-by. Each of them carries his/her story similar to our own, and therefore let's give them sufficient level of dignity that they had few years ago. Based on the preventive recommendations of Berešová (2002), it is necessary to carefully 
prepare for the old age of the person itself or his/her relatives. Despite the fact that the situation in Slovakia is sufficiently legally treated, the issue of domestic violence against the seniors is still new. Prevention would not only avoid mistreatment with this group of people but it could offer practices that would help every family member fully live their last years of life.

\section{References}

Bérešová A. (2002). Prevencia kriminality u starých ludí - Ústav sociálnej medicíny LF UPJŠ Košice. „Podpora zdravia” ročník VII. pp. 12-13.

Biggs S., Phillipson C.H., Kingston P. (1995). Elder Abuse in Perspective. Buckingham.

Haškovcová H. (2004). Manuálek o násilí. Brno.

Kalvach Z. a kol. (2004). Geriatrie a gerontologie. Praha.

Koval Š. (2001). Obete zanedbávania, zneužívania a týrania v starobe. „Prehladné referáty“ pp. 140-143.

Lubelcová G., Džambazovič R. (2008). Sociálne deviácie a kriminalita ako aktuálne společenské problémy. Bratislava.

Repková K., Balogová B. (2013). Prevencia zlého zaobchádzania so staršími l’udmi ako verejná politika. Bratislava.

Sedláková D. (2013). Prevencia zlého zaobchádzania so staršimi ludimi ako priorita Svetovej zdravotníckej organizácie. [In:] K. Repková, B. Balogová. Prevencia zlého zaobchádzania so staršími ludimi ako verejná politika. Bratislava.

Smetanová D. (2015). Domestic violence against seniors in the Slowak Republic. [In: ] K. Jagielska, J.M. Łukasik, N.G. Pikuła.Violence Against the Elderly: Challenges, Research, Action. Toronto.

Smetanová D. (2015). Možnosti a limity pomoci sociálneho pedagóga pri násilí na starších ludoch = Possibilities and limits of the help of social pedagogue forcing with elderly people. [In:] MMK 2015. Hradec Králové.

Ševčík D., Špatenková N. (2011). Domáci násilí. Bratislava.

Špatenková N. (2011). Gerontagogika. Olomouc.

Violence Against Elderly People. (1993). Strasbourg.

Voňková J., Huňková M. (2004). Domácí násilí z pohledu žen. Praha. 
